\title{
Health Technology Assessments in Radiology in Germany: Lack of Demand, Lack of Supply
}

\section{Health-Technology-Assessments in der Radiologie in Deutschland: Fehlende Nachfrage, fehlendes Angebot}

Authors

Carolin Winkelmann ${ }^{1,5}$, Thomas Neumann ${ }^{1,5}$, Jan Zeidler², Anne Prenzler², Bodo Vogt ${ }^{1,4,5}$, Frank K. Wacker ${ }^{3,5}$

Affiliations

1 Chair in Empirical Economics, Otto-von-GuerickeUniversity Magdeburg, Germany

2 Center for Health Economics Research Hannover (CHERH), Leibniz University Hannover, Germany

3 Department of Diagnostic and Interventional Radiology, Hannover Medical School, Hannover, Germany

4 Chair in Health Economics, Institute of Social Medicine and Health Economics, Otto-von-Guericke-University Magdeburg, Germany

5 Research Campus STIMULATE, Otto-von-GuerickeUniversity Magdeburg, Germany

Key words

health technology assessment, radiology, efficacy analysis, efficiency analysis, health economics

received 27.08 .2018

accepted 20.12.2018

Bibliography

DOI https://doi.org/10.1055/a-0838-6253

Published online: 14.2.2019

Fortschr Röntgenstr 2019; 191: 635-642

(c) Georg Thieme Verlag KG, Stuttgart · New York ISSN 1438-9029

Correspondence

Carolin Winkelmann

Lehrstuhl für empirische Wirtschaftsforschung,

Otto-von-Guericke-Universität Magdeburg, Fakultät

für Wirtschaftswissenschaft, Universitätsplatz 2,

39106 Magdeburg, Germany

Tel.: ++49/3 91/6758205

carolin.winkelmann@ovgu.de

\section{ABSTRACT}

Background Health technology assessments (HTAs) are an interdisciplinary method to support sustainable, evidencebased healthcare decisions. They systematically assess medical products, procedures, and technologies with respect to medical, economic, legal, social, and ethical aspects.

Method This review analyzes the current use of HTAs in radiology in Germany and discusses challenges associated with
HTAs. In particular, incentive structures of various players in the healthcare field involved in HTA implementation are considered for both the inpatient and outpatient sectors. Taking into account that the Joint Federal Committee (G-BA) has different authority between sectors ("ban reservation" for inpatients and "authorization right" for outpatients), we focus on the repercussions on reimbursement for new diagnosis or treatment methods by statutory health insurance companies. Results The G-BA's authority implicitly creates a paradox in terms of incentives to implement and finance HTAs: in the outpatient sector HTAs are considered necessary to evaluate new medical services while players may not have sufficient incentive to implement and finance HTAs in the inpatient sector.

Conclusion Characteristics of HTAs differ widely with respect to the items to be assessed. Therefore, an HTA for drug effectiveness is not easily transferable to radiological procedures. Within radiology, each method must be assessed individually (e. g. according to tumor stage). Despite these challenges, systematic compilation and critical assessment (regarding both cost and medical effectiveness) of available evidence should be a basic component of evidence-based radiology. As companies in healthcare fail to invest in studies that advance evidence-based radiology and considering the lack of incentive for such investments, public funding institutions need to accept the challenge to support studies that assess the benefit of radiological procedures.

Key Points:

- HTAs should be a basic component of evidence-based radiology.

- G-BA's authority implicitly creates a paradox in terms of inventives to implement and finance HTAs.

- University hospitals and public funding institutions need to support studies that assess the benefit of radiological procedures.

\section{Citation Format}

- Winkelmann C, Neumann T, Zeidler J et al. Health Technology Assessments in Radiology in Germany: Lack of Demand, Lack of Supply. Fortschr Röntgenstr 2019; 191: 635-642 


\section{ZUSAMMENFASSUNG}

Hintergrund Health-Technology-Assessments (HTA) sind eine interdisziplinär anzuwendende Methode zur Unterstützung nachhaltiger, evidenzbasierter Entscheidungen im Gesundheitswesen. Sie untersuchen in einem systematischen Prozess medizinische Produkte, Verfahren und Technologien unter medizinischen, ökonomischen, juristischen, sozialen und ethischen Aspekten hinsichtlich ihres Einsatzes in der medizinischen Versorgung.

Methode In dieser Übersichtsarbeit wird die aktuelle Verbreitung von HTA in der Radiologie in Deutschland betrachtet. Es werden Anreizstrukturen für die Durchführung von HTA diskutiert und die sich daraus ableitenden Herausforderungen für die Akteure im Gesundheitswesen im stationären und ambulanten Sektor erörtert. Dies erfolgt vor dem Hintergrund des zwischen den Sektoren bestehenden Unterschieds im Entscheidungsprozess darüber, welche Leistungen durch die gesetzlichen Krankenkassen erstattet werden. Es wird insbesondere betrachtet, welche Auswirkungen sich aus dem Verbotsvorbehalt (stationär) bzw. Erlaubnisvorbehalt (ambulant) des Gemeinsamen Bundesausschusses (G-BA) bezüglich der Erstattung neuer Diagnose- und Behandlungsmethoden ergeben.
Ergebnisse Aus den Befugnissen des G-BA ergibt sich hinsichtlich der Anreize zur Durchführung und Finanzierung systematischer Nachweise von Effektivität und Effizienz medizinischer Leistungen implizit ein Paradox: Im ambulanten Sektor sind derartige Nachweise ein notwendiges Instrument, während im stationären Sektor keine ausreichenden Anreize für die Akteure bestehen, in die Durchführung solcher Bewertungen der gleichen Leistung zu investieren.

Schlussfolgerung Es zeigt sich, dass der Bewertungsgegenstand gravierende Unterschiede innerhalb des HTA begründet. Bewertungsprozesse, die zur Überprüfung der Effektivität von Arzneimitteln etabliert sind, können nicht einfach auf radiologische Verfahren übertragen werden. Bei der Bewertung einzelner radiologischer Verfahren muss extrem differenziert, z. B. nach Tumorstadien, vorgegangen werden. Trotz dieser Herausforderungen sollte eine systematische Übersicht und kritische Bewertung verfügbarer Evidenz sowohl zur medizinischen Wirksamkeit als auch der Kosteneffizienz ein elementarer Baustein in der evidenzbasierten Radiologie (EbR) sein. Da Unternehmen im Gesundheitswesen die EbR nicht vorantreiben, sind öffentliche Fördermittelgeber gefordert, Studien zur Innovations- und Nutzenbewertung von bildgebenden radiologischen Verfahren zu unterstützen.

\section{Introduction}

As a result of the shortage of resources in the health care industry, decision-makers are forced to increasingly consider the economic efficiency of services in addition to the medical justification. In the past the health care policy discussion focused on regulating the pharmaceutical sector. Prior to the Act on the Reform of the Market for Medicinal Products becoming effective in 2011, pharmaceutical companies were able to freely set the prices for their products after receiving clinical approval by the European Medical Agency or the Federal Institute for Drugs and Medical Devices. Regulatory instruments like reference prices and prescription advice issued by Federal Joint Committee based on therapeutic assessment only late took effect. According to the Act on the Reform of the Market for Medicinal Products, pharmaceutical companies must present a value dossier to the Federal Joint Committee following drug approval. The dossier must prove the additional benefit of the pharmaceutical over the appropriate comparator. If a positive additional benefit is proven, discounts are negotiated with the National Association of Statutory Health Insurance Funds. Following clinical approval, pharmaceuticals are also tested internationally with respect to their eligibility for reimbursement. The British National Institute for Health and Clinical Excellence assesses the cost effectiveness of new pharmaceuticals based on Health Technology Assessments (HTAs) - systematic assessments to determine effectiveness and efficiency - and health economics models and provides recommendations for reimbursement of these products [1].

To date, medical devices as used in radiology have not been the focus of the health care policy discussion. Although, for example, the Institute for Quality and Efficiency in Health Care, which is involved in the evaluation of the value dossier, has been promoting expansion of the Act on the Reform of the Market for Medicinal Products to include medical devices, the discussion has primarily involved medical devices that remain in the body. The EU Medical Device Regulation marks a fundamental change in this market.

At first glance, it is surprising that the effectiveness and efficiency of medical devices play practically no role in the health care policy discussion. Although large medical systems (like CT and MRI units) are regulated in the statutory health care sector by authorization restrictions and minimum quantities, the systems are often used in patient care. According to the Federal Office of Statistics, the number of CT units in German hospitals has increased in the period of 2012 to 2016 from 1463 to 1537 and the number of MRI units from 891 to 987 [2]. At the same time, the number of hospitals in Germany has decreased from 2017 to 1951 [3]. According to the 2011 Barmer GEK physician's report, $6 \%$ of the German population (4.88 million) underwent at least one CT examination in 2009 and a further 7.2\% $(5.89$ million) underwent at least one MRI examination [4]. The total cost was estimated at 1.76 billion Euros, including 1.25 billion Euros for the outpatient sector, which accounts for $3.2 \%$ of the treatment costs in the statutory health care sector [4]. Despite the high demand for radiological imaging, there seems to be both a low demand for and supply of valid effectiveness and efficiency data. There are multiple reasons for this: although the fundamental technical suitability of an imaging device (based on technical parameters) and the technical quality of images are to be examined, radiology expertise is required to obtain a finding with clinical relevance. Even when the often overlooked factor of radiology 


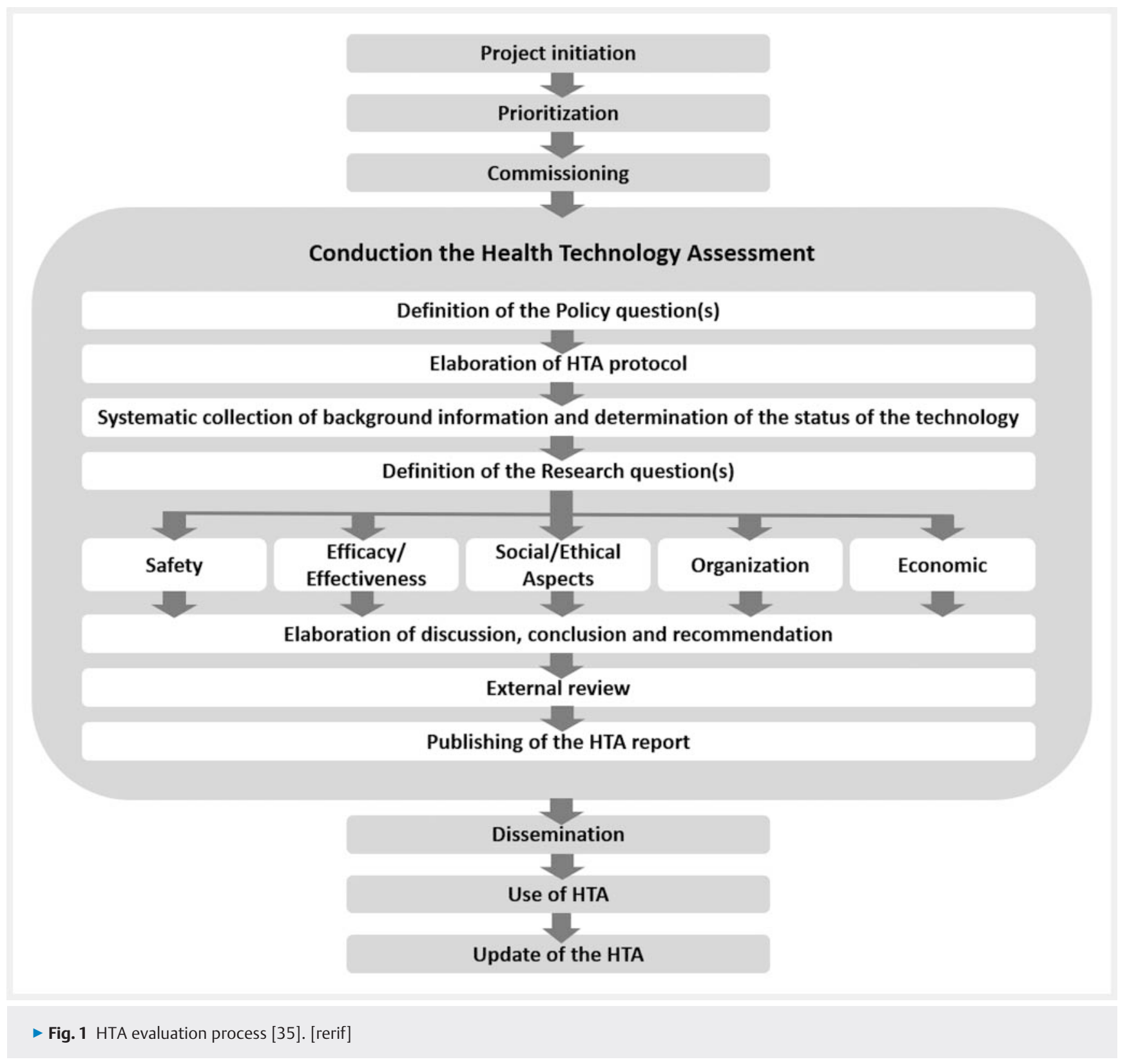

expertise is ignored, it is difficult to perform primary studies regarding treatment relevance in radiology. The potential effects of results from systematic research are also questionable. Moreover as a result of these basic conditions, there is a lack of incentive to finance medical and economic studies as well as reviews of these studies (e. g. by an HTA) in radiology. Details are discussed in the following with a focus on use in diagnostic radiology.

\section{HTAs in radiology}

Per definition, an HTA is a method to be used on an interdisciplinary basis for the systematic and transparent evaluation of medical methods and technologies with respect to medical, economic, legal, social, and ethical aspects with the goal of supporting (medical) decision processes. The term technology in this case re- lates not only to technical devices but also to medications, instruments, procedures, and methods. The core of the HTA report is systematic review of the effectiveness and efficiency of the technology to be evaluated [5]. - Fig. 1 shows the assessment process of an HTA which starts with determination of the question (the PICO model can help here [6]).

Diverse methods and tools were developed to support the analysis of the literature in an HTA. Methods for assessing the medical and economic literature are discussed in the following. The methods differ depending on the technology and the purpose. Therefore, levels of evidence according to evidence-based medicine (EBM) were defined to evaluate the effectiveness of pharmaceuticals, for example. Results from meta-analyses and systematic reviews of randomized controlled trials (RCT) have the highest evidence and expert opinions have the lowest [7]. However, these levels of evidence cannot be transferred to the 
- Table 1 Levels of evidence of radiodiagnostic studies, source: [26], pg. 674.

\begin{tabular}{|c|c|c|}
\hline $\begin{array}{l}\text { grade of } \\
\text { recommendation }\end{array}$ & level of evidence & type of study \\
\hline A & $1 \mathrm{a}$ & $\begin{array}{l}\text { systematic overview of radiodiagnostic studies with level of evidence } 1 \text { or a clinical decision } \\
\text { algorithm validated on the basis of multiple methods }\end{array}$ \\
\hline A & $1 \mathrm{~b}$ & $\begin{array}{l}\text { independent blind comparison of method and reference method performed in a representative } \\
\text { spectrum of consecutive patients who underwent both methods }\end{array}$ \\
\hline A & $1 c$ & $\begin{array}{l}\text { radiodiagnostic result whose specificity is so high that a positive finding definitively provides the } \\
\text { diagnosis and whose sensitivity is so high that a negative diagnosis definitively rules out the } \\
\text { diagnosis }\end{array}$ \\
\hline B & $2 \mathrm{a}$ & systematic overview of radiodiagnostic studies with level of evidence $\geq 2$ \\
\hline B & $2 b$ & $\begin{array}{l}\text { independent blind comparison of method and reference method performed in non-consecutively } \\
\text { recruited patients or in a narrowly defined patient group who underwent both methods, or a clinical } \\
\text { decision algorithm without validation }\end{array}$ \\
\hline B & $3 a$ & systematic overview of studies with level of evidence $\geq 3$ \\
\hline B & $3 b$ & $\begin{array}{l}\text { independent blind comparison of method and reference method performed in a representative } \\
\text { spectrum of patients although all patients did not undergo both methods }\end{array}$ \\
\hline C & 4 & the reference method was not used independently or in a blinded manner \\
\hline D & 5 & expert opinion without explicit critical assessment or on the basis of physiological considerations \\
\hline E & 6 & case report or study of the technical efficiency of a new method \\
\hline
\end{tabular}

assessment of radiology methods since RCTs are not the gold standard here ( $>$ Table $\mathbf{1})$.

These differences were discussed for the first time by the Canadian Evidence-Based Radiology Working Group [8] which coined the phrase evidence-based radiology (EBR). The goals of EBM and EBR are the same: derive valid statements regarding the effectiveness of medical measures, apply them in practice, and integrate individual clinical expertise with the best available external evidence from systematic research [7]. However, the special features of radiology are taken into consideration and other target variables and assessment criteria are used in EBR. - Table 2 shows the target variables of radiodiagnostic studies with these building on one another (e.g. diagnostic accuracy cannot be achieved without technical quality). Various assessment sheets are used to record and evaluate studies in accordance with these target variables in HTAs. - Table 3 was developed by the Scottish Intercollegiate Guidelines Network (SIGN) and shows the requirements regarding the quality of such studies. $\mathbf{T a b l e} 4$ provides an overview of HTA reports in radiology in the period 2012-2017.

One challenge when evaluating new large diagnostic systems is the use of these systems for a wide range of diseases from a herniated disk to cancer. Even when the use of an imaging method is considered with respect to only one tumor entity, there are significant differences in the follow-up of the different tumor stages and the various treatment paths that affect the value of a diagnostic method. Therefore, clear advantages of PET-CT were determined in a study regarding PET-CT follow-up compared to neck dissection. However, these results only apply to N2 stages and the authors emphasize that it does not seem possible to apply the results to the $\mathrm{N} 3$ stage $[9,10]$. In consideration of the increasingly differentiated approach to different receptor- and gene-
- Table 2 Target variables of radiodiagnostic studies, source: [26], pg. 673 .

\begin{tabular}{|c|c|}
\hline $\begin{array}{l}\text { technical } \\
\text { parameters }\end{array}$ & $\begin{array}{l}\text { - image resolution, image noise, grayscale range, } \\
\text { sharpness, imaging parameters }\end{array}$ \\
\hline $\begin{array}{l}\text { diagnostic } \\
\text { accuracy }\end{array}$ & $\begin{array}{l}\text { - sensitivity, specificity, positive and negative } \\
\text { predictive value }\end{array}$ \\
\hline diagnostic value & $\begin{array}{l}\text { number of cases in which the radiology finding } \\
\text { was helpful for diagnosis }\end{array}$ \\
\hline therapeutic value & $\begin{array}{l}\text { number of cases in which the radiology finding } \\
\text { was helpful for treatment } \\
\text { - number of cases in which clinical intervention } \\
\text { could be avoided based on the radiology finding }\end{array}$ \\
\hline $\begin{array}{l}\text { patient-relevant } \\
\text { benefit }\end{array}$ & $\begin{array}{l}\text { - advantages for patients when using radiology } \\
\text { imaging vs. not using } \\
\text { - morbidity that could be prevented based on } \\
\text { radiology imaging }\end{array}$ \\
\hline economic benefit & - cost-benefit or cost-efficiency ratio \\
\hline
\end{tabular}

associated tumor entities, a study regarding the detection of metastases in "breast cancer" no longer seems up-to-date, for example. Moreover, secondary factors like the expertise of the reporting physicians and the process quality play a role in diagnostic processes. With respect to benefits, factors such as selection of the appropriate imaging method and inclusion of the radiologist in clinical decision processes are as important as technical qualities.

In addition to a medical evaluation, economic studies are identified and evaluated in an HTA. These include cost efficiency studies and cost-benefit studies [11]. The former evaluate alternative 
- Table 3 QUADAS checklist for evaluating the method-related quality of diagnostic studies, source: [22], pg. 363.

\begin{tabular}{|c|c|}
\hline number & question \\
\hline 1 & $\begin{array}{l}\text { does the patient population in the study correspond to the } \\
\text { potential spectrum of patients for which the test is to be } \\
\text { used? }\end{array}$ \\
\hline 2 & are the patient selection criteria clearly described? \\
\hline 3 & was the correct reference method selected? \\
\hline 4 & $\begin{array}{l}\text { was the time interval between implementation of the test } \\
\text { and the reference method short enough to ensure no } \\
\text { change in the condition of the patient in the interim? }\end{array}$ \\
\hline 5 & $\begin{array}{l}\text { was the reference method used in all patients or at least a } \\
\text { random sampling of the patients? }\end{array}$ \\
\hline 6 & $\begin{array}{l}\text { did all patients undergo the same reference method re- } \\
\text { gardless of the result of the test of interest? }\end{array}$ \\
\hline 7 & $\begin{array}{l}\text { was the reference test performed independent of the test } \\
\text { (i. e., the test was not part of the reference method)? }\end{array}$ \\
\hline 8 & $\begin{array}{l}\text { was the implementation of the test described in such detail } \\
\text { that it would be possible to replicate the same problem? }\end{array}$ \\
\hline 9 & $\begin{array}{l}\text { was the implementation of the reference method described } \\
\text { in such detail that it would be possible to replicate the same } \\
\text { problem? }\end{array}$ \\
\hline 10 & $\begin{array}{l}\text { were the test results interpreted without knowledge of the } \\
\text { results of the reference method? }\end{array}$ \\
\hline 11 & $\begin{array}{l}\text { were the results of the reference method interpreted } \\
\text { without knowledge of the test results? }\end{array}$ \\
\hline 12 & $\begin{array}{l}\text { were the same clinical data that would be available if the } \\
\text { test was being performed in clinical practice available for } \\
\text { interpretation of the test results? }\end{array}$ \\
\hline 13 & $\begin{array}{l}\text { are uninterpretable or non-final test results included in the } \\
\text { study? }\end{array}$ \\
\hline 14 & $\begin{array}{l}\text { is an explanation for patient drop-outs included in the } \\
\text { study? }\end{array}$ \\
\hline
\end{tabular}

Test $=$ the diagnostic method of interest, reference method $=$ the selec ted gold standard.

technologies (e.g. the use of MRI compared to X-ray) by linking cost and effectiveness parameters. A comparison study of followup regimens after rectal cancer surgery with and without computed tomography over a course of almost 9 years elucidates the fact that it takes significant effort to collect comparative data in this context and the results are not definitive even with intensive planning and large patient numbers. The question could not be answered by this study [12].

In diagnostic radiology, every target variable shown in - Table 2 can theoretically be an effectiveness parameter [13]. In addition, the perception of patients (PRO - patient reported outcomes) is becoming increasingly important in HTAs. To date, this has only been taken into consideration in interventional radiology [14-16]. The call for patient-centered diagnostic radiology can be interpreted as a start in this direction [17]. In health economics, particularly patient-relevant outcomes such as increased qual- ity of life, increased life years, or reduced morbidity are of interest. In cost-utility analyses, complex utility values like quality-adjusted life years (QALY) or health-related quality of life (HRQOL) are used. An incremental approach in which the additional costs of an innovation compared to the standard procedure are determined and divided by the additional benefit resulting from the innovation to form the incremental cost-effectiveness ratio is used here to compare two alternatives. This reflects the costs per additional unit of utility (e.g. QALY, increased life years, HRQOL) [11]. It is typically not possible to observe direct patient-relevant effects in a comparison of diagnostic measures in one study. Health economics models that evaluate the long-term effects and costs of the use of a diagnostic method including the subsequent therapeutic effect can be used here [18].

\section{HTAs: lack of demand, lack of supply}

It is interesting to analyze HTA results for which no statement regarding evidence can be made since, for example, only studies of poor quality are available but the method has nonetheless become established in health care. There are two possible reasons for this lack of evidence: (1) the so-called publication bias [5] (only studies with positive results are published) and (2) a lack of incentive to conduct the corresponding studies.

The following focuses on the incentive structures for the creation of primary studies and HTAs in diagnostic radiology and the organizational challenges. The pharmaceutical sector is used for comparison. Even though pharmaceuticals are pharmacological goods and radiology devices are medical devices, they are both used in patient care and their use is reimbursed by statutory health insurance and private health insurance.

There is a high degree of diversity among large radiology systems with respect to both products and suppliers. Numerous manufacturers offer a range of MRI and CT systems with various modifications. At least in theory, the product life cycle is short (according to the depreciation table of the Federal Ministry of Finance, the useful life is 8 years [19]). The Committee on Scientific Instrumentation of the German Research Society states that large systems are to be replaced within a period of ten years and that diagnostic systems can only remain up-to-date for five years [20].

The life cycle of medical devices is characterized by intensive feedback between practice, research, and development often resulting in product modifications [18]. In the case of pharmaceuticals, modifications are not possible after approval and require new research and development phases and clinical trials. The duration of a patent for pharmaceuticals is approx. 8-12 years minus the research and development time. After that time the pharmaceutical is usually in competition with generics. The patent situation for large radiology systems is usually complex. The rights for many patents held by the largest manufacturers are relinquished early for common use. In addition, there are no "generics". The underlying technology is complex and the currently valid standards are often met only by a few international companies. Innovations are usually implemented on the established technology platforms of these companies, often in cooperation with university hospitals. 
- Table 4 Overview of the number of HTA reports in radiology in the period 2012 - 2017, source [23], pg. 594

\begin{tabular}{|c|c|c|c|}
\hline publication year & organ system & imaging modality & source \\
\hline \multirow[t]{2}{*}{2017} & breast & Mammo, MRI & {$[24]$} \\
\hline & head/neck & PET-CT & [10] \\
\hline \multirow[t]{3}{*}{2016} & lung & CT & {$[25]$} \\
\hline & lung & CT, DCE-CT, FDG-PET-CT & {$[26]$} \\
\hline & all & PET-CT, PET-MRI & [27] \\
\hline \multirow[t]{2}{*}{2015} & breast & CT & {$[28]$} \\
\hline & abdomen & СТC & [29] \\
\hline \multirow[t]{2}{*}{2014} & neuro & MR-DWI, CT & {$[30]$} \\
\hline & all & MRI & {$[31]$} \\
\hline \multirow[t]{2}{*}{2013} & abdomen & TE & [32] \\
\hline & abdomen & Sono, CT, MRI & [33] \\
\hline 2012 & cardio & CT-angio, angio & [34] \\
\hline
\end{tabular}

The approval process for pharmaceuticals and large radiology systems also differs greatly. While the approval of pharmaceuticals is essentially performed by the European Medical Agency (EMA) for all of Europe, the requirements for the approval of medical devices previously differed on a national level. These requirements were harmonized by the EU Medical Device Regulation. The goals of approval also differ. Pharmaceuticals must provide evidence of efficacy, safety, and pharmacological quality in doubleblind RCTs for clinical approval, while CE certification is required for medical devices in Europe. "The aim of the CE marking is to symbolize the conformity of a product with the levels of protection of collective interests imposed by the total harmonization directives and to indicate that the economic operator has undergone all the evaluation procedures laid down by Community law in respect of his product" (EC no. L 220/23 dated 8/30/1993). As a result, the focus is on safety and technical performance. The extent to which the device is better than a comparator or increases patient benefit does not play a role in CE certification. Therefore, RCTs are not relevant for approval and there is no incentive for manufacturers to conduct and finance corresponding studies. Instead, manufacturers conduct studies to show individual performance advantages over other suppliers. However, these studies are often not randomized, the scope and investment are minimal, and the studies tend to highlight technical features rather than the fundamental benefit of a technology.

When evaluating the reimbursement process for diagnostic radiology services, a differentiation between the inpatient and outpatient sector is necessary. It differs greatly from the reimbursement process for pharmaceuticals as outlined in the introduction. In Germany inpatient services are primarily billed using diagnosis-related groups (DRGs). The DRG catalog (published by the Institute for the Hospital Remuneration System) includes all billable DRGs. All general hospital services required to care for a pa- tient (defined according to $\S 2$ of the Hospital Remuneration Act) are reimbursed based on the rates defined there. As a result of the ban reservation of the Federal Joint Committee - everything is allowed in the inpatient sector unless prohibited by the Federal joint Committee in accordance with § 137c SGB V - for now every new examination and treatment method can be used in the hospital, thereby promoting the development of innovative methods [21]. However, the use of innovative methods in the inpatient sector does not automatically result in corresponding reimbursement. To receive separate payment in such cases, an application can be submitted for new examination and treatment methods ( $\S 6$ paragraph 2 Hospital Remuneration Act). Payments for approved new examination and treatment methods are set for a fixed term and in a case-based manner. Individual new examination and treatment methods are integrated in the DRG catalog in subsequent years in the form of DRGs or supplementary payments.

It is largely at the discretion of the individual hospital to decide on an economic basis which (new) examination and treatment methods will be used for providing patient care. Accordingly, each hospital would theoretically have an interest in data regarding the effectiveness and cost efficiency of imaging methods. Based on this individual assessment, it is difficult to determine the affect health economics studies regarding imaging technologies would have on investment decisions in a particular hospital. Therefore, hospitals could decide to introduce a technology despite a minimal proven advantage, for example to expand their own position in the market, to retain employees, to comply with guidelines, or to secure additional revenue through third-party orders. The internal and external marketing goals of a hospital cannot be ignored here [5]. The results of an HTA that does not take such system effects into consideration can represent at most only part of the decision process of a hospital. 
Analysis by the Federal Joint Committee for inclusion in the uniform value scale is mandatory in the outpatient sector (authorization right). The Federal Joint Committee must make recommendations regarding the "recognition of the diagnostic and therapeutic benefit of the new method and its medical necessity and economic efficiency - also in comparison to methods already performed at the expense of the health insurance funds - according to current scientific knowledge in the relevant therapy approach" (§135 paragraph 1 SGB V). If the service is included in the uniform value scale, it can be billed as part of the physicians' budgets. However, in radiology imaging, e. g. MRI, reimbursement is fundamentally not related to a specific MRI technology. The part of the body being examined (head, chest, etc.) and whether contrast agents or dynamic sides were used are relevant for billing. Under consideration of certain minimum standards, the MRI technology that was used is not relevant. This shows again that individual manufacturers do not have an incentive to conduct corresponding studies relevant to the Federal Joint Committee.

\section{Conclusion and outlook}

The commercial incentive and the interest are not significant enough on the part of customers as well as suppliers of large radiology systems to individually invest in the evaluation of a technology. The same is true for the creation of systematic reviews (like HTAs). Even with sufficient medical and economic evidence, it is unclear whether, for example, hospital management would take the information obtained by an HTA into consideration in economic decisions. To sum it up: No demand - no supply.

However, the systematic compilation and evaluation of the medical and economic literature are a fundamental component of EBR that should not be neglected. Physicians cannot be expected to be EBR-compliant when the evidence is so low that it is hardly possible to derive practical instructions from the literature. For this reason, there should be a desire for more evidence in the literature. In light of the described problems regarding incentive, university hospitals as well as public funding agencies have an important role in the promotion and implementation of medical studies and studies on medical economics. It would be desirable for additional funding sources for innovation and benefit assessment of imaging methods to be made available for example to cost carriers to allow more independent research in this area. As a result, a scientifically substantiated basis could be created to be able to use and further develop diagnostic methods in an evidence-based manner in the future.

\section{Conflict of Interest}

The authors declare that they have no conflict of interest.

\section{Literatur}

[1] Prenzler A, von der Schulenburg JMG. Institutionen der Vierten Hürde. In: Schoffski O, von der Schulenburg JMG, (eds) Gesundheitsökonomische Evaluationen. 4th ed Berlin, Heidelberg: Springer-Verlag; 2012: 437-456
[2] Statistisches Bundesamt. Anzahl der medizinisch-technischen Großgeräte in deutschen Krankenhäusern nach Gerätetyp in den Jahren von 2012 bis 2016. Statista - Das Statistik-Portal, n.d. https://de.statista. com/statistik/daten/studie/166519/umfrage/medizinisch-technischegrossgeraete-in-krankenhaeusern

[3] Statistisches Bundesamt. Anzahl der Krankenhäuser in Deutschland in den Jahren 2000 bis 2016. Statista - Das Statistik-Portal, n.d. https://de. statista.com/statistik/daten/studie/2617/umfrage/anzahl-der-kranken haeuser-in-deutschland-seit-2000

[4] Grobe TG, Dörning H, Schwartz FW. BARMER GEK Arztreport 2011: Schwerpunkt: Bildgebende Diagnostik - Computer- und Magnetresonanztomografie. St. Augustin: Asgard-Verlag; 2011

[5] Greiner W. Health Technology Assessment (HTA). In: Schoffski O, von der Schulenburg JMG, (eds) Gesundheitsökonomische Evaluationen. 4th ed Berlin, Heidelberg: Springer-Verlag; 2012: 457-479

[6] Scottish Intercollegiate Guidelines Network (SIGN). SIGN 50: a guideline developer's handbook. Edinburgh, 2015

[7] Kunz R, Ollenschläger G, Raspe H et al. Lehrbuch evidenzbasierte Medizin in Klinik und Praxis. 2nd ed Köln: Dt. Ärzte-Verl; 2007

[8] The Evidence-Based Radiology Working Group. Evidence-based radiology: A new approach to the practice of radiology. Radiology 2001; 220 : $566-575$

[9] Mehanna H, Wong WL, McConkey CC et al. PET-CT Surveillance versus Neck Dissection in Advanced Head and Neck Cancer. The New England Journal of Medicine 2016; 374: 1444-1454

[10] Mehanna H, McConkey CC, Rahman JK et al. PET-NECK: a multicentre randomised Phase III non-inferiority trial comparing a positron emission tomography-computerised tomography-guided watch-and-wait policy with planned neck dissection in the management of locally advanced (N2 / N3) nodal metastases in patients with squamous cell head and neck cancer. Health Technology Assessment 2017; 21: 1 - 122

[11] Drummond MF, Sculpher MJ, Claxton K et al. Methods for the Economic Evaluation of Health Care Programmes. Oxford: Oxford University Press. 2015

[12] Mant D, Gray A, Pugh S et al. A randomised controlled trial to assess the cost-effectiveness of intensive versus no scheduled follow-up in patients who have undergone resection for colorectal cancer with curative intent. Health Technology Assessment 2017; 21: 1 - 86

[13] Hollingworth W, Jarvik JG. Technology assessment in radiology: Putting the evidence in evidence-based radiology. Radiology 2007; 244: 31 - 38

[14] Hinrichs JB, Hasdemir DB, Nordlohne M et al. Health-Related Quality of Life in Patients with Hepatocellular Carcinoma Treated with Initial Transarterial Chemoembolization. CardioVascular and Interventional Radiology 2017; 40: 1559-1566

[15] Bernstein OA, Campbell J, Rajan DK et al. Randomized Trial Comparing Radiologic Pigtail Gastrostomy and Peroral Image-Guided Gastrostomy: Intra- and Postprocedural Pain, Radiation Exposure, Complications, and Quality of Life. Journal of Vascular and Interventional Radiology 2015; 26: $1680-1686$

[16] Marker DR, Perosi N, Ul Haq F et al. Percutaneous Cecostomy in Adult Patients: Safety and Quality-of-Life Results. Journal of Vascular and Interventional Radiology 2015; 26: 1526-1532.e1

[17] Swan JS, Pandharipande PV, Salazar GM. Developing a Patient-Centered Radiology Process Model. Journal of the American College of Radiology 2016; 13: $510-516$

[18] Siebert U, Jahn B, Mühlberger N et al. Entscheidungsanalyse und Modellierungen. In: Schoffski O, von der Schulenburg JMG, (eds) Gesundheitsökonomische Evaluationen. 4th ed Berlin, Heidelberg: Springer-Verlag; 2012: $275-324$

[19] Bundesministerium der Finanzen. AfA-Tabelle für den Wirtschaftszweig „Gesundheitswesen“ (Aktenzeichen: IV A 8-S 1551-7/95). 1995 http:// www.bundesfinanzministerium.de/Content/DE/Standardartikel/The 
men/Steuern/Weitere_Steuerthemen/Betriebspruefung/AfA-Tabellen/ 1995-01-13-afa-23.pdf?__blob=publicationFile\&v=3

[20] Lagier H. Stellungnahme zur Geräteausstattung in Radiologischen/Neuroradiologischen Universitätskliniken. 2012 http://www.dfg.de/down load/pdf/foerderung/programme/wgi/stellungnahme_radiologie.pdf

[21] Hess R. Die ordnungspolitische Funktion einer einheitlichen Leistungsgestaltung - der Gemeinsame Bundesausschuss und das Institut für Qualität und Wirtschaftlichkeit im Gesundheitswesen. In: Rebscher H, (ed) Gesundheitsökonomie und Gesundheitspolitik im Spannungsfeld zwischen Wissenschaft und Politikberatung. Heidelberg: Economica Verlag; 2006: 441 - 458

[22] Felder-Puig R, Mad P, Gartlehner G. Diagnostische Studien. Wiener Medizinische Wochenschrift 2009; 159: 359-366

[23] Gizewski ER, Forsting M, Krombach GA et al. Health Technology Assessment (HTA): Entwicklung im Gesundheitswesen und Potenzial in der Radiologie. Der Radiologe 2014; 54: 589 - 598

[24] Teljeur C, Moran P, Harrington P et al. The HIQA's Health Technology Assessment of Breast Screening: Highlighting Some of the Challenges Posed by Evaluations of Screening Programs. Value in Health: The Journal of the International Society for Pharmacoeconomics and Outcomes Research 2017; 20: $1000-1002$

[25] Field JK, Duffy SW, Baldwin DR et al. The UK Lung Cancer Screening Trial: a pilot randomised controlled trial of low-dose computed tomography screening for the early detection of lung cancer. Health technology assessment (Winchester, England) 2016; 20: 1-146

[26] Qureshi NR, Rintoul RC, Miles KA et al. Accuracy and cost-effectiveness of dynamic contrast-enhanced CT in the characterisation of solitary pulmonary nodules-the SPUtNIk study. BMJ open respiratory research 2016; 3: e000156

[27] Universitätsklinik für Radiologie und Nuklearmedizin Magdeburg. RAD294-COMPARE Onko PET: Vergleich der diagnostischen Genauigkeit zwischen PET/CT und PET/MR bei onkologischen Fragestellungen. 2016 https://www.drks.de/drks_web/navigate.do?navigationld=trial. HTML\&TRIAL_ID=DRKS00009720
[28] Ruile G, Djanatliev A, Kriza C et al. Screening for breast cancer with Breast-CT in a ProHTA simulation. Journal of comparative effectiveness research 2015; 4: 553-567

[29] Halligan S, Dadswell E, Wooldrage K et al. Computed tomographic colonography compared with colonoscopy or barium enema for diagnosis of colorectal cancer in older symptomatic patients: two multicentre randomised trials with economic evaluation (the SIGGAR trials). Health technology assessment (Winchester, England) 2015; 19: 1-134

[30] Wardlaw ], Brazzelli M, Miranda $\mathrm{H}$ et al. An assessment of the costeffectiveness of magnetic resonance, including diffusion-weighted imaging, in patients with transient ischaemic attack and minor stroke: a systematic review, meta-analysis and economic evaluation. Health Technology Assessment 2014; 18: 1 -368, v-vi

[31] Kisser A, Mayer ], Wild C. Opportunities and strategies to drive appropriate use of MRI in Austria: LBI-HTA Projektbericht Nr.: 80. Wien: Ludwig Boltzmann Institut für Health Technology Assessment. 2014

[32] Steadman R, Myers RP, Leggett L et al. A Health Technology Assessment of Transient Elastography in Adult Liver Disease. Canadian Journal of Gastroenterology 2013; 27: 149-158

[33] Westwood M, Joore M, Grutters ] et al. Contrast-enhanced ultrasound using SonoVue ${ }^{\circledR}$ (sulphur hexafluoride microbubbles) compared with contrast-enhanced computed tomography and contrast-enhanced magnetic resonance imaging for the characterisation of focal liver lesions and detection of liver metastases: a systematic review and costeffectiveness analysis. Health Technology Assessment 2013; 17: 1-243

[34] Gorenoi V, Schönermark MP, Hagen A. CT-Koronarangiografie versus konventionelle invasive Koronarangiografie bei der KHK-Diagnostik: DIMDI. 2012

[35] Busse R, Orvain J, Velasco M et al. Best practice in undertaking and reporting health technology assessment - Working group 4 report. International Journal of Technology Assessment in Health Care 2002; 18 : $361-422$ 